\title{
A KAPCSOLATOK EMBEREIVÉ NEVELNI. GONDOLATOK A 21. SZÁZADI TANÍTÁS KIHÍVÁSAIRÓL ÉS ANNAK KUTATÁSÁRÓL
}

\author{
CZÓK BRIGITTA \\ Eszterházy Károly Egyetem \\ Neveléstudományi Doktori Iskola
}

\begin{abstract}
Néhány évtizede a nemzetközi tanárok egyfajta hátizsákos turistához hasonlítottak, akik az adott országot bejárva helyi iskolákban tanítottak. Mára az egyik legmagasabban minősített intézmények, ahol presztízs tanulókkal foglalkozni. Jelen tanulmányban két megközelítés felvázolására teszek kísérletet: a magyarországi nemzetközi iskolákat vezető és ott tanító tanárok 21. századi tanításról és annak kihívásairól alkotott nézeteit vázolom fel a kutatói szerep és a terepmunka alatt gyűjtött tapasztalatok mellett. A megközelítés talán sajátos, de ha a tanítás változik vagy nemzetközi tanárokkal folytatunk munkát, akkor óhatatlan a kutatók stratégiáinak megújítása is. Vagyis célszerü, ha a kettő együtt jár. Tettem mindezt annak a reményében, hogy a magyar szakmai közökben is ismertebb legyen, amiből mind ők mind az őket kutatók ötletet meríthetnek belőle a további munkájukhoz.
\end{abstract}

„Heti három órai találkozásból is egy hihetetlen jó személyes, őszinte kapcsolatot lehet kialakítani, amikor a gyerek megnyílik és képes tőlünk tanulni. Azért ezt a kapcsolatot ki kell tudni építeni, hogy tudjanak tőlünk, tudjanak rólunk tanulni." (T.O.,Cambridge-i tanterv szerint tanító iskola intézményvezetőjele)

Közel egy évig tartott felvenni a kapcsolatot velük, most pedig itt ül velem szemben a képernyő másik oldalán. Kedélyesen, kedvesen, segítőkészen beszél, mintha régi ismerősök lennénk. Még az olyan személyesnek hitt kérdésekre is könnyedén ad választ, minthogy „Szerinted attól szakmaibb egy tanár, ha nemzetközi közegben mozog?” vagy „Miért tartod magad nemzetközi tanárnak?” Már - már provokatívan próbálom lehámozni a „személyest”, hogy meg tudjuk ragadni a pusztán szakmai jegyeket, ezáltal talán a jövő tanárjelöltjeit segíthetem. Erre felnevet: „Magasztos ambíciók, de a kettő elválaszthatatlan egymástól ebben az esetben. Minden a kapcsolatok egyensúlyán múlik.”

1 Jelen tanulmányban a kutatásban részt vevő iskolák pontos nevét és vezetőjét nem említem meg egyrészt az adatvédelmi egyezségünk miatt, másrészt pedig a tanulmány fókusza a gondolatiságon és nem az adott iskola bemutatásán van. 
Kapcsolatok egyensúlya... pedig a Zoom szobába való beengedés előtti pillanatokban rendkívül vegyes érzésekkel készítettem fel magam az interjúra. Hiszen sok körön vagyunk túl már, legalább tíz email, ugyanennyi továbbítás az iskolai titkárok részéről, három telefonhívás, öt sms és egy személyes megkeresés, végül én csak úgy nyomjam meg az „admit” (hozzáadás, beengedés) gombot és neki ez csak két másodpercébe telik, ami nekem 5 hónapig tartott. Ráadásul arcon ver a valóság, hogy a több hónapig gyalult, legegyszerüsített kérdéseim megválaszolása mégsem olyan könnyü.

Bevezetésnek szánt soraim a doktori munkám alatt készült terepnaplóm részlete, amellyel szerettem volna egy kutatás árnyoldalait és a katedra mögötti tanári munkát ilyen módon is szemléltetni. Ilyenkor hangoznak el olyan mondatok, mint például a mottónak választott idézet, amelyet érdemes közelebbről is megnéznünk, ha meg akarjuk érteni, a nemzetközi (sokszor magán is) iskolák kultúráját, világát. Jelen tanulmányban e két megközelítés felvázolására teszek kísérletet: a magyarországi nemzetközi iskolákat vezető és ott tanító tanárok 21. századi tanításról alkotott nézeteit és stratégiái, a kutatói szerep és a munka alatt gyüjtött tapasztalatok. Mindezt annak a reményében, hogy mind a tanári hivatást gyakorló, mind az őket kutatók ötletet meríthetnek belőle.

\section{A kutatói szerepről}

A társadalomtudomány történetében ott volt egy nagy fordulat, amikor a pozitivista, laboratóriumi körülmények közötti vizsgálatokat előnyben részesítő „karosszék” tudományt felváltotta a terepmunkára építő, adott kultúrában, társadalomban élők értelmezéseit interpretáló gyakorlati tudomány. (Vö.: Biczó, 2003, Bohannan-Glazer,2006, Falus,2004) Ez utóbbi már a 20. században is tudománytalannak, szubjektívnek „kemény tudományok” tekintélyét semmibe vevőnek hatott, ám a 21. századra már ezek a megközelítések is fontos adalékokkal, „résztudománnyal” (Nahalka 2002) járulhatnak hozzá a neveléstudományi kutatásokhoz. De mindez hogyan jelenhet meg akár egy konkrét doktori kutatásban 2021-ben?

Antropológus hátteremből fakadóan számomra nincsenek jelentéktelen dolgok az adatgyűjtés során. Meglepő módon számos tanulmány születik a pedagógusok reflektálásának szükségességéről, de keveset olvashatunk a neveléstudományi kutatás gyakorlásáról, a kutatók visszaemlékezéseiről. A kettőt úgy tekintem, mint az érme két oldalát, egyik nincs a másik nélkül. Azaz, ha nem ismertetjük egy adott időszak, adott kutatásának hátterét, akkor az elemzések során bemutatott jelenségeket, gondolatokat hajlamosan vagyunk általánosítani és a teljes pedagógus társadalomra rávetíteni. Pedig ezek pillanatképek még ha longitudinális vizsgálatra is kerül sor. Egy kimerevített helyzet, egy adott témáról való beszélgetés, amelyeket a kutatásban résztvevőkkel együtt izgalmas összeállítani. 
Amikor meg szeretnék érteni egy pedagógiai jelenséget - nevezetesen a tanárok nézeteit a tanításról - akkor próbálok minél több időt velük tölteni és minél több iskolai eseményen, iskolalátogatáson részt venni. A nemzetközi iskolák kutatása előtti, többnyire magyar iskolalátogatások során a legkülönösebb pillanat, amikor bemutattak egy tantestületnek vagy kisebb munkaközösségnek, így voltam már „kistanár”, tréner, mentor, viselkedésvizsgáló és szakmai segítő, de kutató egyszer sem. El is gondolkoztam mit rontok el, hiszen az előkészületek során gondosan megküldtem a mérőeszközeimet, a kutatási ismertetőket és a rövid a bemutatkozómat.

Aztán mire a nemzetközi iskolákhoz kerültem, a napjainkban sűrűn emlegetett járványhelyzet minden addigi rutinomat a kukába dobta. Nem lehetett se iskolai látogatás, se személyes jelenlét, se bemutatkozás, ezáltal az iskoláknak a pandémiát kifogásnak használva könnyű volt elutasítani vagy figyelembe se venni. Ám annak a maroknyi iskolának, akik vállalták az együttműködést mindezek ellenére, hirtelen felszínre törtem, mint kutató, ők pedig megjelentek, mint tanárok. Maszk és felvett szerepek nélkül néha néma percekben

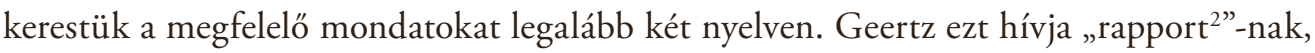
Boglár Lajos pedig úgy említi ezt a helyzetet az „Így kutatunk mi... (2004) tanulmánykötetben, hogy a terepen nincs elmélet, ott csak az ember van. Úgy gondolom pont emiatt fogalmazódhattak meg értékes, elgondolkodtató kijelentések a napjaink tanítási kihívásairól.

\section{Külföldi iskolák - nemzetközi tanárok}

Magyarországon eddig kevés tanulmány született az itt élő külföldi pedagógusokról. Többnyire a külföldi tanulók, vendégoktatók mint kuriózumként jelentek meg kutatásokban, pedig jóval nagyobb arányban vannak jelen az oktatási palettán. Magyar nyelven különbséget kell tennünk a nemzetközi iskola és a külföldi iskola között, ugyanis az előbbi egy sokkal szűkebb kategória a Nemzetközi Iskolák Kutatóközösségének (ISC Research) meghatározása szerint. Nemzetközi iskolának tekinthető az az oktatási intézmény, ahol az óvodai, általános és középiskolai tanterv bármilyen kombinációját alkalmazzák, az oktatás pedig teljes egészében vagy többségében angol nyelven zajlik egy nem angol anyanyelvü országban. Vagy ha egy iskola olyan országban található, ahol az angol nyelv hivatalos nyelv ugyan, de az ország nemzeti tantervétől eltérő, nemzetközi tantervet kínál és az iskola irányultsága is nemzetközi. ${ }^{3}$ (ISC Research)

Ezen túlmenően a külföldi iskola alatt minden olyan közoktatási intézményt érthetünk, amelyek a 2011.évi CXC. köznevelési törvény szerint meghatározott nyilvántartásban

2 Vörös-Frida 2004: 413

3 ISC Research nemzetközi iskola meghatározása: https:/www.iscresearch.com/about-us/who-we-are (2021.02.21.) 
szerepelnek, törzskönyvezett közoktatási intézmények (azaz van OM azonosítójuk), amelyeket az oktatásért felelős miniszter vett nyilvántartásba és engedélyezte működésüket. Továbbá olyan intézmények, amelyek külföldi alapítványi vagy egyesületi szervezésben is müködhetnek és nem nemzetiségi intézményként vannak akkreditálva. Jelen tanulmány csak a nemzetközi iskolák tanárai közt végzett kutatásra fókuszál.

Az ISC Research 1994 óta kezdte el kutatni a nemzetközi iskolákat, de még mindig elég új területnek számít, hiszen míg 2000-ben csak 2584 iskolát tekintettek nemzetközinek, 2020-ra 11451 intézményre növekedett világszerte. Ez a tanárok szempontjából azt jelentette, hogy míg 2000-ben 90 ezer tanárra volt szükség ezekben az iskolákban, mára ez a szám több mint félmillió ( 554 ezer). ${ }^{4}$

Golnhoffer Erzsébet (2006) Az iskola belső világa című tanulmánykötetében, egyrészt az iskolák nagyon bonyolult társadalmi, gazdasági, kulturális környezetben működnek, így belső életük komplex, összetett világa nehezen írható le. Másrészt az az iskolák sajátosságainak csak egy része látható, az iskolákban tevékenykedők nézeteiről kevés információval rendelkezünk. Megemlíti azt is, hogy az intézményeknek „alkati” jellemzőik is vannak, amelyeket a bennük tevékenykedő emberek által képviselt értékek, attitűdök, normák, tevékenységek formálnak. (Golnhoffer,2006) Ehhez kapcsolódóan Fives és Buelh (2012) az iskola tanárok munkájára való hatásáról ír, hogy az iskolai kultúra, a tanárkollégák tevékenységei, a társ tanítás (co-teaching), a mentor tanár mind befolyásolja a tanári nézetek megnyilvánulását. (McMullen et al.,2006 idézi Fives-Buelh,2012)

Savva (2013) szerint pedig a nemzetközi iskolák, olyan magán intézmények, ahol elsősorban nem a fogadó ország lakosainak gyerekei tanulnak, hanem a nemzetközi, multinacionális vállalatok nemzetközi szervezetek, alapítványok dolgozóinak, diplomaták, misszionáriusok gyermekei. A tanárok gyakran csak két éves meghatározott szerződéssel tanítanak és ezek a tapasztalatok pozitívan járulnak hozzá a tanárok interkulturális fejlődéséhez.

Ugyanakkor mások kritikaként említik, egyrészt, hogy a külföldi iskolák egyfajta elszigetelt közösségek, így a nemzetközi tanárok nem igazán ismerik a fogadó ország kultúráját, nyelvét. (Hayden - Thompson, 2016) Másrészt Williams-Gualandi (2019) - aki a nemzetközi tanárok interkulturális megértésről és identitásról írt disszertációt - szükséges feltételnek tartaná, ha a nemzetközi környezetben tanító tanárokban jobban tudatosulna, hogy milyen közegben tanítanak és kötelezné őket egy interkulturális továbbképzésre. Mert annak ellenére, hogy van valami féle kulturális felkészítő a kiutazásuk előtt, sokan tanári képesítés nélkül érkeznek, nemhogy interkulturális képzésen vettek volna részt, ami a különböző sztereotípiák és osztálytermi konfliktusok veszélyét hordozza magában. Ellenben ezek a típusú intézmények szerinte megfelelő helyek lehetnek arra, hogy a tanárok

4 ISC Research adatbázis: https://www.iscresearch.com/data (2021.02.21.) 
fejlesszék a interkulturális készségeiket ${ }^{5}$, személyre szabottan tudjanak differenciálni a „kultúravakság” ${ }^{”}$ helyett és bővítsék a módszertani repertoárjukat.

\section{Nemzetközi és hazai szintézis a tanári nézetekről}

A nemzetközi iskolai környzetet kutatása mellett a tanárok gondolkodásmódjának vizsgálata napjainkban továbbra is egy rendkívül szerteágazó, innovatív és népszerủ téma világszerte a neveléstudományban, most csak két szintetizáló tanulmányról teszek említést. Patricia Ashton (2015) áttekintő tanulmányában fel is hívja a figyelmet arra, hogy e kutatási téma népszerűsége nem volt mindig így. Ashton (2015) fejezete Tanári nézetek nemzetközi kutatási kézikönyvében (International Handbook of Research on Teachers' Belief) az elmúlt hatvan év kronológiai áttekintését adja a nézetkutatások főbb trendjeiről. Tanulmányának alapja azok a neveléstudományi, neveléslélektani és pszichológiai akadémiai és kutatási kézikönyvek, amelyekben a nézetkutatások kulcsfogalmai, elméleti megközelítései, fordulópontjai megjelentek.

Másrészt a hazai kutatások kérdéseit és eredményeit Kálmán Orsolya (2013) vetette össze a nemzetközi trendekkel. A magyar folyóiratokban, monográfákban, tanulmánykötetekben publikált kutatásokat öt főbb szempont szerint elemezte (nézetfogalom értelmezési keretei, kutatásban résztvevők, metodológia, nézetek tartalma és struktúrája) és tovább gondolta, hogyan lehetne a nézetvizsgálatokat tovább fejleszteni és az aktuális hazai pedagóguskutatás területén alkalmazni.

E két tanulmány összevetés során arra juthatunk, hogy nemzetközi diskurzusban úgy tünik, hogy az utóbbi bő egy évtizedben a nézetkutatások részben „beolvadtak” a szakmai identitás tágabb kutatási területébe. A pedagógusidentitás, a nézetek és a kompetenciák kapcsolódásának, egymásra épülésének és feszültségeinek kérdései nyitottak maradtak, mind a pedagógusok, pedagógusjelöltek egyéni, csoportos szintjén, mind pedig a tanárképzés, a folyamatos szakmai fejlődés rendszerének szintjén.

Összegzésképpen elmondható, hogy a hazai és nemzetközi nézetkutatásokban pedagógusok, pedagógusjelöltek, oktatók nézeteinek vizsgálatakor három jól körvonalazható trend bontakozott ki. Jellemzően kutatás tárgyává teszik: a pedagógusok a tantárgyi tanításhoz kötődő nézeteit, a tanulással, tanítással, episztemológiával, tanári szakmával kapcsolatos

\footnotetext{
$5 \mathrm{Az}$ amerikai szakirodalom a kompetencia fogalmát nem használja az interkulturalitás esetében 6 Culture blinded szó szerinti megfogalmazásban kultúrvak, ami azt jelenti ebben az esetben, hogy a tanár a tanítása során tudatosan koncentrál arra, hogy mindegyik kultúrától semleges legyen és kizárólag arra figyeljen, hogy embereket tanít. Viszont ez a nemzetközi iskolákban meglehetősen rossz stratégia, mert leszűkíti a tanár kreatíviását és akaratlanul is etnocentristává teszi a tanítást.
} 
nézeteit, valamint olyan, a hétköznapi pedagógiai gyakorlatban újdonságnak számító területekkel kapcsolatos nézeteik alakulását, mint például az inklúzió, multikulturalizmus, IKT eszközök használata. (Kálmán,2013)

De mindezek a fentebb említett nemzetközi esettanulmányok következtetései hogyan jelennek meg Magyarországon? Milyen kihívásokat fogalmaznak meg a tanítás területén a nemzetközi iskolákat vezető intézményvezetők (akik sok esetben tanárként is tanítanak)? Az Oktatási Hivatal Közoktatási Információs Iroda (KIR-STAT) 2019-es statisztikája szerint 25 külföldi iskolának minősített intézmény szerepel a nyilvántartásukban, amelyből tíz tekinthető nemzetközi iskolának a fentebb leírt meghatározás szerint, így jelen tanulmányhoz hét nemzetközi iskola intézményvezetőjével ${ }^{7}$ készült interjúból emelem ki a közös pontokat, vagy sajátosságokat a tanításukkal kapcsolatosan.

\section{Tanári nézetek a tanítás kihívásairól}

Közös pontként mindegyiküknél megjelent a kapcsolatok fontossága, a szociális kompetenciák és a globális állampolgárságra való nevelés, összefüggések meglátása és megértése. A fókusz a tanulók szükségleteinek kielégítésére van, amellyel együtt jár az tanulás megtanítása és a kreativitás, gyermeki kíváncsiság minél hosszabb ideig való megtartása.

„Hát talán valahogy elsőként gyerekek önállóságra való nevelését említeném. A gyermekek önálló kreatív gondolkodásra nevelése. A gyerekeknek a meghagyni az alapvető gyermeki kíváncsiságot és a tanulás tanítása, mint fontos feladat jelenik meg. Természetesen ezeket valamilyen szinten szét lehet választani úgymond tantárgyakra, bár ezek között szépen átmenetet lehet képezni, hogy az egységesnek tünjön és egybe lehessen a területeket összefogva a gyerekeknek bemutatni. Hogy az összefüggéseket lássák, és egyben lássák a világot. Nem, mint kis puzzle darabokat, hanem a nagy képet mutassuk és annak kirakóiról beszéljünk." (T.O., Cambridge-tanterv szerint tanító iskola)

Van, ahol egy konkrét tantárgy kereteiben jelenik meg (Global Perspectives a Cambridge-i tantervben vagy Global Awareness az IB programban), van, ahol a tanári standardok és kompetenciák része vagy önmagában az iskolai kultúra és környezet ad rá lehetőséget, hogy a diákok közelebb kerüljenek a nyitottabb gondolkodásmódhoz.

„A Cambridge-iben meg volt a lehetőség, hogy két három iskolával együtt vettünk részt egy kémia órán, hogy lássák, hogy egy globális csapatban ez hogy mủködik, és mondtam nekik, hogy később így fogtok felnőttként globálisan dolgozni, kutatócsoportokban részt

7 Jelen tanulmányban a kutatásban részt vevő iskolák pontos nevét és vezetőjét nem említem meg, csupán egy monogramot és a nemzetközi tanterv típusát jelölöm. Egyrészt az adatvédelmi egyezségünk miatt teszek így, másrészt pedig a tanulmány fókusza a gondolatiságon és nem az adott iskola bemutatásán van. 
venni. Érdekli őket az, hogy egy indiai osztállyal egy tokiói osztállyal vagy egy krakkói osztállyal együtt dolgoztak egy projekt során. Ez a Cambridge-nek is a célja, igazából nálunk a globális szemléletmód egyrészt egy beépített tantárgy elsőtől kezdve, ami tudatosan erre neveli a gyerekeket. De ennél sokkal jobban arra nevelődnek, hogy testvériskolai kapcsolat vagy a későbbiekben cserediákok alakuljanak ki. (T.O.,Cambridge-tanterv szerint tanító iskola)

Ahhoz, hogy ezek a lassan kibontakozó készségek és kompetenciák kialakuljanak, illetve a nemzetközi közegben a tanárok helyt álljanak néhány kihívást megfogalmaztak. Egyrészt napjainkban egyre nehezebb diáknak lenni és nemcsak a járványhelyzet miatt. Ezért a nemzetközi iskola az a hely, ahol családias és biztonságos a közeg, sok lehetőség van a kipróbálásra, ami folytán a diákok felépítik a jövőjüket.

„Régebben úgy tartották, hogy a fejlődő világban dolgozni nagyszerủ volt, látni ahogyan felkészíted az embereket a 20. századra. És ez az oktatásban nagyon nehezen változik, hogy még mindig 20. századi. De sajnos a 21. században élünk. Az igazi kihívás, amivel az oktatás szembenéz, hogy egy nagyon más világra kell felkészíteni a fiatalokat. Ezért van kompetencia és készég alapú tantervünk, ahol olyan dolgokat hangsúlyozunk, mint helytállás, tisztelet, empátia, integritás, becsület, tolerancia...mert erre lesz szüksége a jövőben." (J.H. Cambridge és magyar tanterv szerint tanító iskola)

A nemzetközi iskolák között vannak keresztény értékrendet tanító, úgynevezett misszionárius iskolák. Itt az elvárás, hogy a tanárok keresztény, angol nyelvet magas szinten beszélő szakember legyen, „akinek az ajándéka az, hogy segít a gyerekeknek és elkötelezi magát a gyerekek fejlesztése mellett. De a tantervünk abszolút nemzetközi, kiegészítő egységekben jelennek meg a keresztény témakörök. Ugyanígy a diákok sem mind keresztények, vannak hinduk, muszlimok, zsidók és ők is ugyanúgy részt vesznek a keresztény órákon. Ilyenkor megtanulják egymást megérteni, kifejezni, amiben ők hisznek és érvelni, kritikusan gondolkodni”. (J.S. IB program alapján tanító keresztény iskola)

A másik már félig említett fókuszpont és egyben kihívás a tanításban, hogy a diákokat a nemzetközi lét és közeg bátorító legyen, ahol kiteljesedhetnek és jobban megismerhetik másokat és ezáltal magukat is.

„Igen ez nemcsak azért fontos mert itt nálunk több nemzetközi gyermek is van és őket elfogadóvá szeretnénk tenni a magyar gyerekek felé, hanem azért is mert a nemzetközi iskola azt is jelenti, hogy sokan közülük valószínű már nem is Magyarországon fogja folytatni a felsőfokú tanulmányait és fel kell, hogy legyenek készülve, hogy máshol máshogy van. Ezért nagyon fontos, hogy a gyerekek minél többet megismerhessenek „itthon ról” a nagyvilágból." (T.Ö. IPC tanterv szerint tanító általános iskola)

Mindezen készségek, képességek és kompetenciák a tanároktól is egészen másfajta szerepeket vár el, más attitűdöket, mintha egy helyi iskolában tanítanának. 
„Az elmúlt években a nemzetközi tanárok sokat változtak. Tíz-tizenöt évvel ezelőtt egyfajta hátizsákos, túrabakancsos tanárság volt. A jelszó az volt: Hajrá, menjünk lássunk világot, keressünk egy kis pénzt és akkor tanítsunk egy helyi iskolában. De ma már messzemenően szakmai és felelősségteljes emberek, ahova nagyon nehéz bekerülni. Mert ha összehasonlítom egy állami iskolával, akkor a nemzetköziben a 15 gyerek mellé 15 különböző kulturális hátteret is kapsz, ami nyelvileg is igazi kihívás. Mert nem érti például az angol humort és másnap sírva jön az anyuka, hogy mi történt. Nem rándíthatod meg a vállad, hogy hát csak vicceltem." (J.H. Cambridge és magyar tanterv szerint tanító iskola)

Legtöbbször a nemzetközi tanárok két-három évig maradnak egy iskolában ezáltal egy országban és egyfajta vándoréletet élnek, sokszor családdal együtt mozognak, ezáltal is nevelik gyermekeiket a nemzetközi létre. „Persze családdal nehezebb, de tudod, ha visszatekintek a pályámra annyira szuper, hogy volt lehetőségem nagyon sokféle emberekkel együtt dolgoznom. Éltem Kínában, Szingapúrban, Hollandiában és emellett 23 másik nemzetközi iskolát tanácsoltam, mentoráltam. Nem tudod egyféleképpen látni a világot és amikor látod, hogy egyik kultúrájú ember hogyan kapcsolódik a másikkal az valami lenyűgöző.” (D.P, angol tanterv szerint tanító iskola)

Egy másik intézményvezető elmondása szerint tanítás nemcsak az akadémikus tudás átadása, hanem „mi megkapjuk a gyereket nyolc órára, többet vannak velünk, mint a szüleikkel.” (T.O.) Így a nevelőmunka során példaképek, akiken felelősség van, hogyan kommunikálnak egymással és a diákok felé, illetve mennyire tudnak egy bizalmi, őszinte és stresszmentes környezetet biztosítani, „ami megfelelő a gyerekeknek arra, hogy tudjanak tanulni benne, tudjanak kérdezni, tudjanak fejlődni." (T.O.)

A biztonságos környezet és példakép mellett a nemzetközi iskolában tanító tanárok, olyan szakemberek, akik folyamatosan fejlesztik magukat, széles látókörrel rendelkeznek és ,a nemzetköziség ad egy olyan plusz tudást, ami nagyon is alkalmazható a hétköznapi tanításban" (T.Ö.) Ehhez kapcsolódóan mivel mindenkivel a járványhelyzet alatt készítettem interjút, úgy tartották, hogy azok az iskolák tudták szerencsésebben megélni ezt az időszakot, akiknél a modern eszközök használata a mindennapos rutin része.

A kutatás során érdekes volt tapasztalni, hogy habár mindegyikük vezetői pozíciót tölt be, abszolút partneri viszont tartanak fenn a tantestülettel. Többen is említették, hogy magukat ugyanúgy tanárnak tartják, néhány óra tanításához ragaszkodnak, szeretnek emberekkel foglalkozni. „Attól, hogy az iskola vezetője vagyok, emellett tanító is. Úgy gondolom a tanári pályán a módszerek és tervek olyanok mint, ahogyan az orvosok is látják mi van a tünetek mögött. Úgy ahogy a te szakmádban van törvényszéki antropológus, én a tanári pályára is bevezetném, hogy törvényszéki tanár, mert maga az hogy törvényszéki magában hordozza, hogy magasan kvalifikált, szakmai ember." ( D.P. angol tanterv szerint tanító iskola) 
Jelen tanulmányban csupán csak villanásszerủen mutattam be azokat a jegyeket, közös pontokat, amelyeket a magyarországi nemzetközi iskolák vezetői említettek. Összegzésként a tanulók oldaláról a kreatív, kritikai, analitikus gondolkodás fejlesztése, összefüggések meglátása a cél, míg a tanárok oldaláról a diákok szükségleteire való odafigyelés, barátságos környezet kialakítása, kompetenciák, készségek fejlesztése az elvárt.

A beszélgetések során megérintett, hogy nem „letudni” akarták a kérdéseket, hanem együtt gondolkodtunk, sokszor vitatkoztunk róluk. Néha már én kezeltem nehezen a csendes, maga elé néző, gondolkodó másik embert, aztán csak annyit mondanak tetszettek nekik a kérdéseim. Volt, aki napokkal előtte is gondolkodott róla és felkészült az interjúra, hogy a válasza tényleg tudjon segíteni. Nos ezek a régen „hátizsákos, túrabakancsos” tanárok egy óra alatt is megtanítottak kiépíteni egy őszinte kapcsolatot és sokat tanultam tőlük, róluk. A „túrakabát alatt” megláthattam a „kosztümöt”, ahogyan bátran néznek a kihívások elé, mert egy hatékony, erőteljes és magasszintű felkészítésen mentek át, amit a nemzetközi élet tapasztalatai adtak nekik.

\section{Felhasznált irodalom:}

2011.évi CXC. köznevelési törvény: https://net.jogtar.hu/jogszabaly?docid=a1100190.tv Ashton, P.T. (2015): Historical Overview and Theoretical Perspectives of Research on Teachers' Beliefs. In: Fives, H. - Gill, M.G. (szerk.) 2015: International Handbook of Research on Teachers' Belief. Routledge. London and New York.Chapter 3, 31-48.

Biczó,G. (2003): Antropológiai irányzatok a második világháború után. Csokonai Kiadó, Debrecen.

Boglár, L. (szerk.) (2004): „ÍGY KUTATUNK MI...” az antropológiai terepmunka módszereihez I. Budapest. Szimbiózis

Bohannan, P- Glazer, M. (szerk.) (2006): Mérföldkövek a kulturális antropológiában. Panem Kiadó, Budapest.

Falus, I. (szerk.) (2004): Bevezetés a pedagógiai kutatás módszereibe. https://regi.tankonyvtar. hu/hu/tartalom/tamop425/2011_0001_531_pedagogia/adatok.html

Fives, H. - Buehl, M. M. (2012). Spring cleaning for the "messy" construct of teachers' beliefs: What are they? Which have been examined? What can they tell us? In:Harris,K.R. - Graham,R - Urdan, T. (szerk..), APA educational psychology handbook: Vol. 2. Individual differences and cultural and contextual factors. Washington, DC: American Psychological Association. 471-499. https://doi.org/10.1037/13274-019 
Geertz, C. (1988): Sűrű leírás. Út a kultúra értelmező elméletéhez. In: Vári, A. (szerk.): Misszionáriusok a csónakban. Akadémiai Kiadó, Budapest.

Geertz, C. (2001): Az értelmezés hatalma. Antropológiai írások. (Niedermüller P. szerk.), Századvég Kiadó, Budapest

Golnhofer, E. (szerk.) (2006): Az iskola belső világa. Nádasi, M. (sorozatszerkesztő): A gyakorlati pedagógia néhány kérdése. http://mek.niif.hu/05400/05468/05468.pdf Hayden, M.- Thompson, J. (2016) International schools: current issues and future prospects. Symposium Book, United Kingdom. https://doi.org/10.15730/books.99

ISC Research International school definition: https://www.iscresearch.com/about-us/ who-we-are

Kálmán, O. (2013): A pedagógusjelöltek és pedagógusok nézetei - hazai kutatások nemzetközi kontextusban In: Kotschy, Beáta (szerk.) Új utak a pedagóguskutatásban: Tanulmánykötet Falus Iván tiszteletére. Eger, Magyarország: Líceum Kiadó, 81-104.

MacLure, M. (1993). Arguing for yourself: Identity as an organizing principle in teachers' jobs and lives. British Educational Research Journal, 19(4), 311-322. https://doi.org/10.1080/0141192930190401

McMullen, M.- Elicker, J. - Goetze, G.- Huang, H.- Lee, S.- Mathers, C.-Yang, H. (2006). Using collaborative assessment to examine the relationship between self-reported beliefs and the documentable practices of preschool teachers. Early Childhood Education Journal, 34 , 81-91. https://doi.org/10.1007/s10643-006-0081-3

Nahalka István (2002): Hogyan alakul ki a tudás a gyerekekben? Konstruktivizmus és pedagógia. Nemzeti Tankönyvkiadó, Budapest

Savva, M. (2013): International schools as gateways for the intercultural development of North-American teachers. Journal ofResearch in International Education, Vol. 12, No. 3, 214-227. https://doi.org/10.1177/1475240913512589

Vörös, M. - Frida, B. (2004): Az antropológiai résztvevő megfigyelés története. In: Letenyei László (szerk.) Településkutatás. L’Harmattan, Budapest, 395-416.

Williams-Gualandi, D. M. (2019): International school teachers' beliefs about intercultural understanding and identity. doctoral dissertation. University of Bath. https://ethos.bl.uk/OrderDetails.do?uin=uk.bl.ethos.782234 